\title{
Scarcity of Drinking Water in Taihu Lake Basin, China: A Case Study of Yixing City
}

\author{
Sha Lou ${ }^{1, *}$, Wenrui Huang ${ }^{1,2}$, Shuguang Liu ${ }^{1,3}$ and Guihui Zhong ${ }^{1}$ \\ 1 Department of Hydraulic Engineering, Tongji University, Shanghai 200092, China; \\ whuang@eng.fsu.edu (W.H.); liusgliu@tongji.edu.cn (S.L.); guihui_zhong@tongji.edu.cn (G.Z.) \\ 2 Department of Civil \& Environmental Engineering, Florida State University, Tallahassee, FL 32306, USA \\ 3 Department of Hydraulic Engineering, Key Laboratory of Yangtze River Water Environment, Ministry of \\ Education, Tongji University, Shanghai 200092, China \\ * Correspondence: lousha@tongji.edu.cn
}

Received: 19 January 2019; Accepted: 18 February 2019; Published: 20 February 2019

check for updates

\begin{abstract}
Water use has been growing globally at more than twice the rate of the population increase over the last century. Water scarcity is one of the main problems facing the world, especially the scarcity of clean and safe drinking water. Scarcity of drinking water is not only relevant in arid or semiarid regions, but also occurs in water-rich regions due to the decline in water quantity caused by pollution or salinity intrusion. As a part of Taihu Lake Basin, a famous water-rich region in China, Yixing City has a total area of $1996.6 \mathrm{~km}^{2}$, including $242.29 \mathrm{~km}^{2}$ from Taihu Lake, 215 rivers with an area of $130 \mathrm{~km}^{2}$, more than 20 ponds with an area of $0.05 \mathrm{~km}^{2}$, and 20 reservoirs with a total capacity of 126 million $\mathrm{m}^{3}$. There always has enough water in Yixing City. However, meteorological conditions and water quality both affect the available drinking water sources. Poor-quality water was used as a drinking water source in Yixing City during a drought event in 2011. Approximately $1.4 \times 10^{7} \mathrm{~m}^{3}$ of poor-quality water was used for drinking water in Yixing city, providing $37.13 \%$ of the total drinking water. It was a source of concern that the water quality was too poor to be used as drinking water and that the water treatment processes were expensive. The scarcity of drinking water has become a serious issue, not only in arid and semiarid regions but also in water towns such as Taihu Lake Basin, and this issue requires society's attention. Many measures should be taken to relieve the drinking water shortage, such as seeking new drinking water sources, protecting the current water source areas, controlling pollution emissions, and implementing effective water resource management.
\end{abstract}

Keywords: drinking water source; drinking water scarcity; water demand; water quality decline

\section{Introduction}

Water scarcity is one of the main problems facing the world [1]. Conflicts between water demand and supply have become more intense recently [2]. Approximately $8 \%$ of the world's population is exposed to water scarcity threats [3]. More than a billion people currently live in water-scarce regions, and as many as 3.5 billion could experience water scarcity by 2025 [4]. Due to the increasing human population and accelerated economic activity, the global water demand will increase from approximately $3500 \mathrm{~km}^{3}$ in 2000 to nearly $5500 \mathrm{~km}^{3}$ in 2050 as shown in Figure 1 [5], with a sharp rise in manufacturing, electricity and domestic supply. However, the amount of available freshwater sources is limited due to the influence of both climate change and a decline in water quality. 


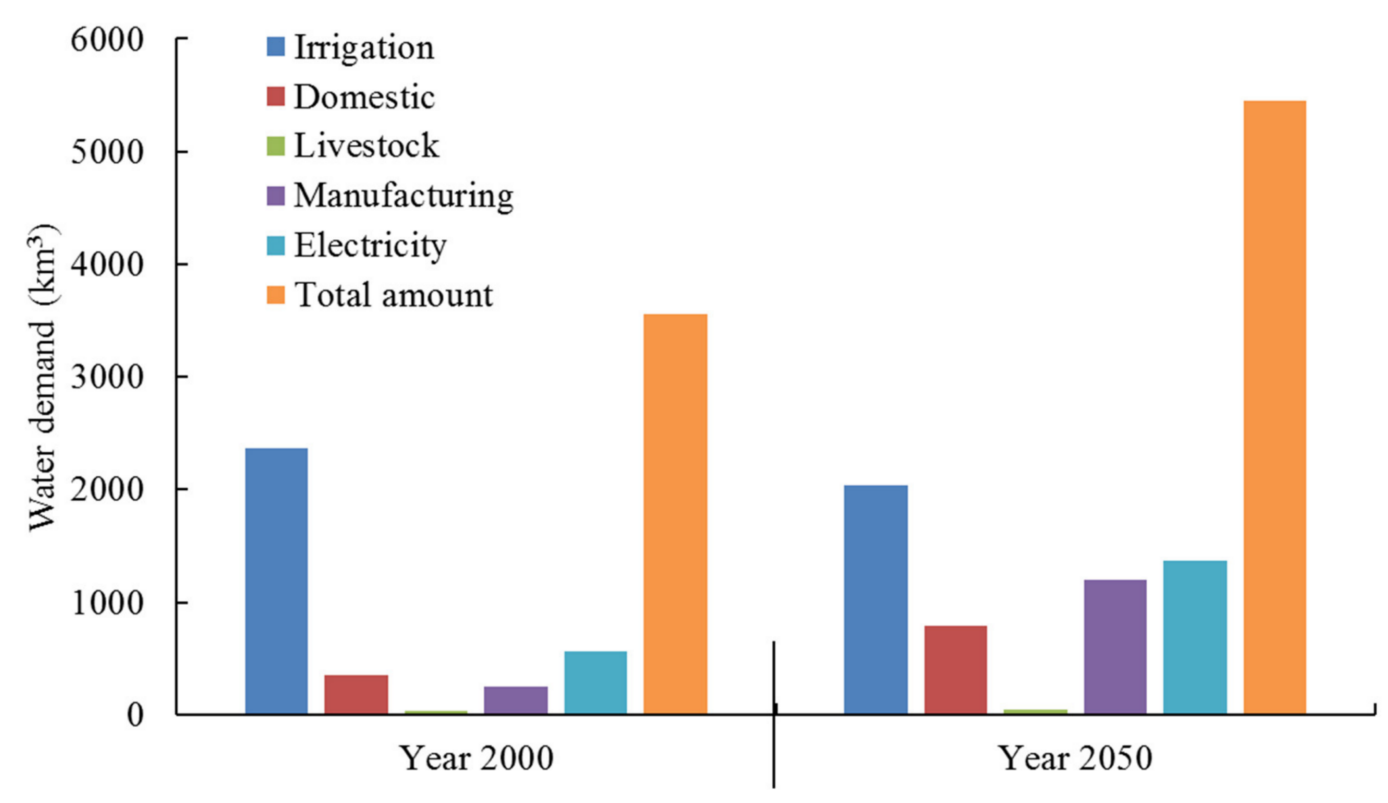

Figure 1. Global water demand (Baseline Scenario 2000 and 2050).

\subsection{Climate-Related Water Scarcity}

Arid and semiarid regions are most obviously water scarce in the physical sense [6]. These areas occupy more than one third of the land surface on the planet and host approximately $30 \%$ of the world's population [7]. In Africa, one third of all nations suffered from clean water scarcity due to very significant inter-and intra-annual variability of climate and water resource characteristics. In particular, Sub-Saharan Africa has the largest number of water-stressed countries on the planet. Water scarcity constrains economic growth and threatens the livelihoods of people in Africa. According to findings presented at the 2012 Conference on "Water Scarcity in Africa: Issues and Challenges" [8], it is estimated that 75 million to 250 million people in Africa will be living in areas of high water stress by 2030. According to Wallace [9], people in the North-Africa belt had less than $1000 \mathrm{~m}^{3}$ water per year in 2000. Within the next 25 years, it will drop below $500 \mathrm{~m}^{3} /$ capita/year in Egypt, the most populous country in this region.

In South America, the average water use per person is $0.01 \mathrm{~m}^{3} /$ day in the semiarid region of Brazil [10], while the World Health Organization states that $0.02 \mathrm{~m}^{3}$ of water per person per day is needed to ensure the basic needs of every person. Due to the high frequency of water scarcity during severe droughts, the use of dams has been limited over the years in Northeast Brazil, which has the second largest number of dams in the world. In Chile, the precipitation ranges from near zero in the north to an annual $2000 \mathrm{~mm}$ in the south, due to a unique geography which causes significant regional differences in per capita water availability. The average water availability is below $1000 \mathrm{~m}^{3}$ /person/year in the north of Santiago, while it is much larger reaching over $10,000 \mathrm{~m}^{3}$ /person/year in the south of Santiago. In drought years, such as 2012, water shortages occur in approximately $88 \%$ of northern Chile, and approximately $20 \%$ of southern Chile [11].

In Europe, water availability per capita varies widely because water supply and people are unevenly distributed. It has been estimated that at least $11 \%$ of Europe's population and $17 \%$ of its territory have been affected by water scarcity. One of the worst droughts occurred in 2003, when one-third of European territory and over 100 million people were affected [12]. Spain is one of the most sensitive countries to climate change in Europe, due to its socioeconomic and geographic features [13]. Renewable water resources in the Jucar River Basin of Spain [14] are nearly 1700 million $\mathrm{m}^{3}$, while water extraction is 1680 million $\mathrm{m}^{3}$, very close to the renewable resource, causing more vulnerability to water scarcity in the future. 
In Asia, Saudi Arabia and other countries in the Middle East, i.e., Qatar, United Arab Emirates, and Kuwait, are already classified by the United Nations as water-scarce nations. Saudi Arabia constitutes the majority of the Arabian Peninsula and is one of the largest arid countries without permanent rivers or lakes. The renewable water resource in Saudi Arabia is $89.5 \mathrm{~m}^{3}$ water per capita per year, which is much lower than the severe water scarcity threshold of $500 \mathrm{~m}^{3}$ per capita per year [15]. In Amman, the capital of Jordan, water needs have risen to $300,000 \mathrm{~m}^{3}$ / day which is $90,000 \mathrm{~m}^{3}$ more than the maximum available daily water level and leads to a deficit of 35 million $\mathrm{m}^{3}$ of water per year [16]. In China, 300 cities out of a total of 662 will have insufficient water supplies and 110 cities will experience severe water shortages in normal water years [17]. The total water shortage is estimated to be $30-40$ billion $\mathrm{m}^{3}$ per year and will be even larger in dry years [18]. The north and northwest regions of China are especially arid and drought prone due to insufficient local water resources and climatic conditions. The amount of renewable water ranges from $0.860 \mathrm{~m}^{3}$ per capita per day in the Hai River basin to $1.841 \mathrm{~m}^{3}$ per capita per day in the Yellow River basin in China [19]. In recent years several exceptional drought disasters occurred in southwest China, such as Yunnan in 2005, Sichuan in 2009, and in other southwest areas in 2009 and 2010, which had a significant impact on local residences' lives and economic development [20].

\subsection{Quality-Related Water Scarcity}

Water scarcity is not only relevant in arid or semiarid regions. The widespread degradation of water quality across the world is one of the most serious water problems threatening human health and ecosystem integrity. The decline in water quantity caused by pollution or salinity intrusion, etc., is a major concern for water resource sustainability. If the quality does not meet the requirements for a water function zone, it causes quality related water scarcity.

In Europe, such as in the Netherlands, water scarcity is less extreme than in Mediterranean regions [21]. Surface water from the rivers Meuse and Rhine account for $40 \%$ of the drinking water production in the Netherlands [22]. However, the current water quality of these rivers does not meet the surface water quality standards that are required by the Water Framework Directive or the target values for drinking water production [23] by the European Environment Agency [24]. In the Meuse River, the concentrations of pharmaceuticals, diagnostic contrast media and endocrine disruptors exceed target values set by the European River Memorandum, which seriously threatens the local drinking water supply [25].

Bangladesh, known as the "land of water," also faces a safe drinking water crisis. In the coastal regions of Bangladesh, safe drinking water scarcity is an acute problem due to saline surface waters [26] and arsenic in groundwater, as well as frequent droughts [27]. Approximately 15 million people are already forced to drink saline water and 30 million people are unable to collect potable drinking water due to a lack of available safe water sources [28].

According to the Chinese national standard GB3838-2002 [29], water quality standard for the function zoning of surface water is divide into five classes in China. Generally, drinking water sources are required to reach Class-I and Class-II water quality standards. However, $47.6 \%$ of river lengths and $72 \%$ of lake areas in China did not meet the water quality standards for drinking water sources, and only $55.1 \%$ of the water function zones reached the standards in 2015 [30]. Water pollution, including accidental water pollution events, have become key factors affecting water supply. Due to spatially distributed water resources, China's water scarcity has mostly been studied in North and Northwest China [31-34]. However, water quality decline caused by increasing pollution [30] has resulted in quality related water scarcity in southern China, which has abundant water. Taking cyanobacterial bloom events in Taihu Lake on the Yangtze Delta as an example, residents in Wuxi City, located on the shore of Taihu Lake, noticed an intolerable odor coming from their water taps on the morning of 29 May 2007. The odor was caused by cyanobacterial blooms due to eutrophication, and a decomposed cyanobacterial scum covered the intake of the water works in Taihu Lake [35].The main drinking water source for the urban area in Wuxi City is the Gonghu Lake, which is in the northern 
part of Taihu Lake. Although there is abundant water in Taihu Lake, most water cannot be used as a drinking water source due to its poor water quality [36]. Because of the odor of tap water and concern about cyanotoxins with these blooms, the local residents consumed bottled water instead of city water derived from the lake. The cyanobacterial bloom caused a drinking water shortage and directly affected approximately two million people who were without drinking water for at least a week.

Water quality or water pollution is rarely regarded as an important factor in water scarcity assessments $[3,37]$. However, water scarcity is often underestimated without considering water quality. Water scarcity is related to not only the amount of water resources but also the water quality. Scarcity in drinking water caused by declining water quality requires urgent attention. Although there is plenty of water in Taihu Lake of southern China, the quality of most of the water in the Lake does not reach the national standard for drinking water sources and cannot be used for drinking water due to its poor quality [36]. Therefore, scarcity of drinking water sources also occurs occasionally in Taihu Lake Basin and more attention to this should be given, especially during drought years.

Many researchers have conducted studies about the water scarcity in arid and semiarid regions. However, only a few have focused on the quality-related water scarcity in water-rich regions. This paper focuses on the drinking water scarcity caused by decline of water quality in Yixing City, Taihu Lake Basin, China. It provides a brief overview of the current water resource and water quality conditions in Taihu Lake Basin. Then it furtherly analyzes the drinking water scarcity during a drought event and discusses its coping measures to overcome the crisis in Yixing City. This paper also suggests few future measures to combat drinking water scarcity in water-rich regions. It could give some suggests for water resource management in Taihu Lake Basin. It may also provide some support for decision-making in the fields of drinking water scarcity, water protection and emergency response in other similar areas. The paper is organized as follows. The methods and data source were introduced in Section 2. A brief description about the conflict between drinking water sources and water demand in Taihu Lake Basin is presented in Section 3. Then, taking Yixing City as an example, drinking water scarcity and coping measures are presented in Section 4. The final part of the paper shows the conclusions.

\section{Methods and Data}

The Standardized Precipitation Index (SPI) and single factor water quality analysis were used in this paper to analyze the influences of meteorological droughts and declines in water quality on scarcity of drinking water in Yixing City, Taihu Lake Basin.

The SPI Index is a meteorological drought index that was first formulated by McKee et al. [38] to define and monitor droughts. It is commonly used to categorize observed rainfall as a standardized departure with respect to a rainfall probability distribution function and to determine the rarity of a drought on a given time scale. The index has been widely used by many researchers [39-42]. It also has been adopted by the US National Drought Mitigation Center for operational use to replace the traditional Palmer Drought Severity Index. The calculation of the SPI index is based on the density and probability function Gamma as shown in Equations (1)-(3).

$$
\begin{gathered}
g\left(x_{k}\right)=\frac{1}{\beta^{\alpha} \Gamma(\alpha)} x_{k}^{\alpha-1} e^{-x_{k} / \beta} \\
G\left(x_{k}\right)=\int_{0}^{x_{k}} g\left(x_{k}\right) d x_{k}=\frac{1}{\beta^{\alpha} \Gamma(\alpha)} \int_{0}^{x_{k}} x_{k}^{\alpha-1} e^{-x_{k} / \beta}=\frac{1}{\Gamma(\alpha)} \int_{0}^{x_{k}} t^{\alpha-1} e^{-t} d t \\
H\left(x_{k}\right)=q+(1-q) G\left(x_{k}\right)
\end{gathered}
$$

where $g\left(x_{k}\right)$ is the probability density function. $x_{k}$ is the amount of precipitation over $k$ consecutive months $\left(x_{k}>0\right)$. The function $\Gamma(\alpha)$ is the gamma function. The $\alpha$ is the form parameter $(\alpha>0)$, and $\beta$ 
is the scale parameter $(\beta>0) . G\left(x_{k}\right)$ is the cumulative probability (time $t=x_{k} / \beta$ ). The cumulative probability is written as $H\left(x_{k}\right) . q$ is the probability of zero precipitation. The cumulative probability, $H\left(x_{k}\right)$ could be transformed to the standard normal random variable with mean zero and variance of one, which is the value of the SPI. The SPI calculation uses rainfall values only, and it can be calculated for a selection of time scales (1-12 months). SPI Values and their interpretation are shown in Table 1.

According to China national standard GB3838-2002 (environmental quality standard for surface water, 2002) [29], single factor water quality analysis was adopted to assess the water quality of the backup drinking water source in Yixing City during a drought event.

$$
P_{i}=\frac{M_{i}}{S_{i}}
$$

where $M_{i}$ is the measured concentration of water quality index $i(\mathrm{mg} / \mathrm{L}) . S_{i}$ is the standard concentration of water quality index $i(\mathrm{mg} / \mathrm{L})$. If $P_{i}>1\left(M_{i}>S_{i}\right)$, the water quality cannot meet the requirement of water quality standard.

Data of precipitation, water resource and demand in both Taihu Lake Basin and Yixing City were collected from the Bulletin of Water Resource in China to analyze the local meteorological condition and the conflict between water demand and available drinking water. Water levels in the main water source and water quality indices in the backup drinking water source in Yixing City, which were surveyed by the local environmental protection and monitoring administration office, were selected to discuss about the influences of meteorological droughts and declines in water quality on scarcity of drinking water in Yixing City.

Table 1. SPI class and interpretation.

\begin{tabular}{cc}
\hline SPI Class & Interpretation \\
$\geq 2.0$ & Extremely wet \\
1.5 to 1.99 & Severely wet \\
1.0 to 1.49 & Moderately wet \\
0.99 to -0.99 & Near normal \\
-1.0 to -1.49 & Moderately dry \\
-1.5 to -1.99 & Severely dry \\
$\leq-2.0$ & Extremely dry \\
\hline
\end{tabular}

\section{Conflict between Water Demand and Available Drinking Water in Taihu Lake Basin}

Taihu Lake Basin $\left(30^{\circ} 7^{\prime} 19^{\prime \prime}-32^{\circ} 14^{\prime} 56^{\prime \prime} \mathrm{N}, 119^{\circ} 3^{\prime} 1^{\prime \prime}-121^{\circ} 54^{\prime} 26^{\prime \prime}\right.$ E) lies on the Yangtze Delta and is bounded to the north by the Yangtze River, to the east by the East Sea and to the south by the connecting Qiantang River, with a total area of $36,895 \mathrm{~km}^{2}$ (Figure 2). As one of the most famous water-rich regions in the world, Taihu Lake Basin is characterized by the presence of many rivers and lakes, including Taihu Lake which is the third largest freshwater lake in China [43]. According to Table 2 [44], the total water resource, including both surface water and groundwater, was increasing in Taihu Lake Basin from 2003 to 2016, except in 2011 and 2013, which recorded relatively lower values of 19.5 billion $\mathrm{m}^{3}$ and 16.1 billion $\mathrm{m}^{3}$, respectively. Precipitation in Taihu Lake Basin during 1954-2016 is shown in Figure 3. In recent years, the precipitation values are lower than the average values in 2011 and 2013 (1119 $\mathrm{mm}$ and $1091 \mathrm{~mm}$ respectively), which were meteorological drought years. After 2013, the annual precipitation keeps increasing. The precipitation trend is consistent with the total water resource distribution in Taihu Lake Basin. 


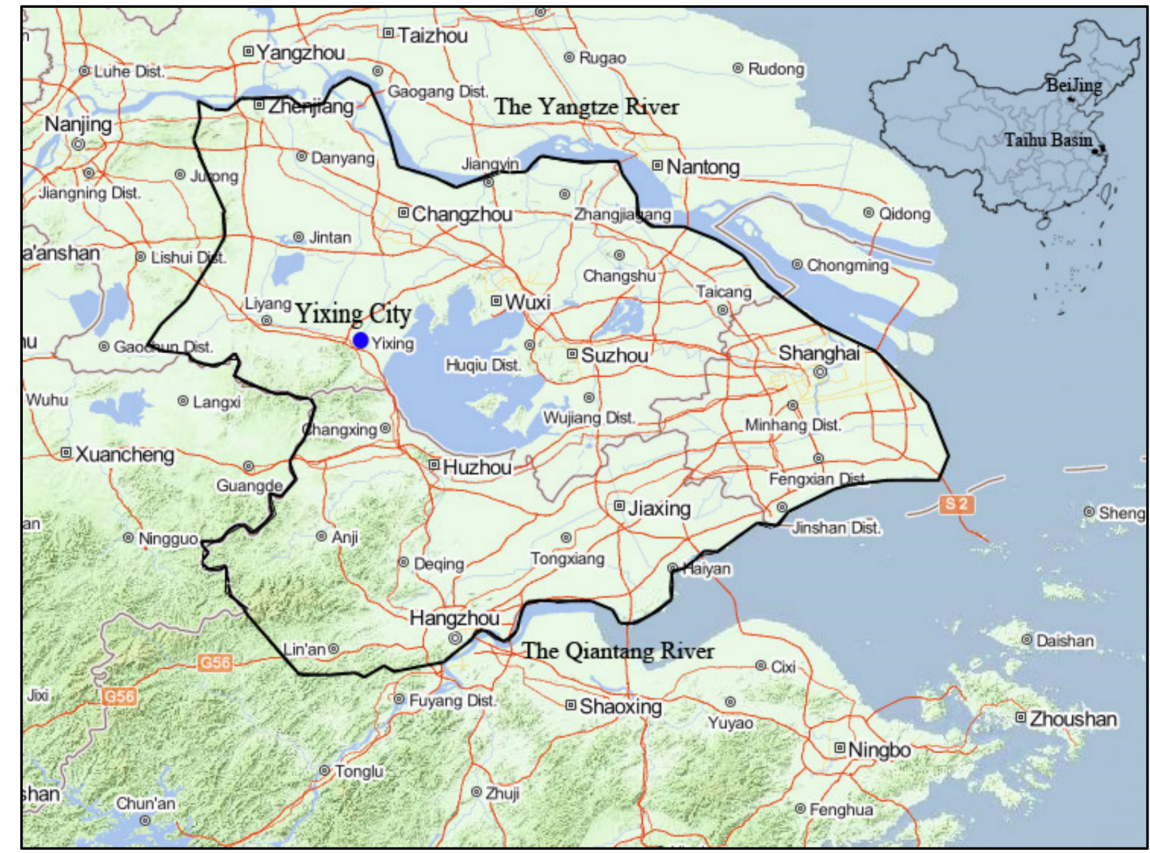

Figure 2. Location of the Taihu Basin.

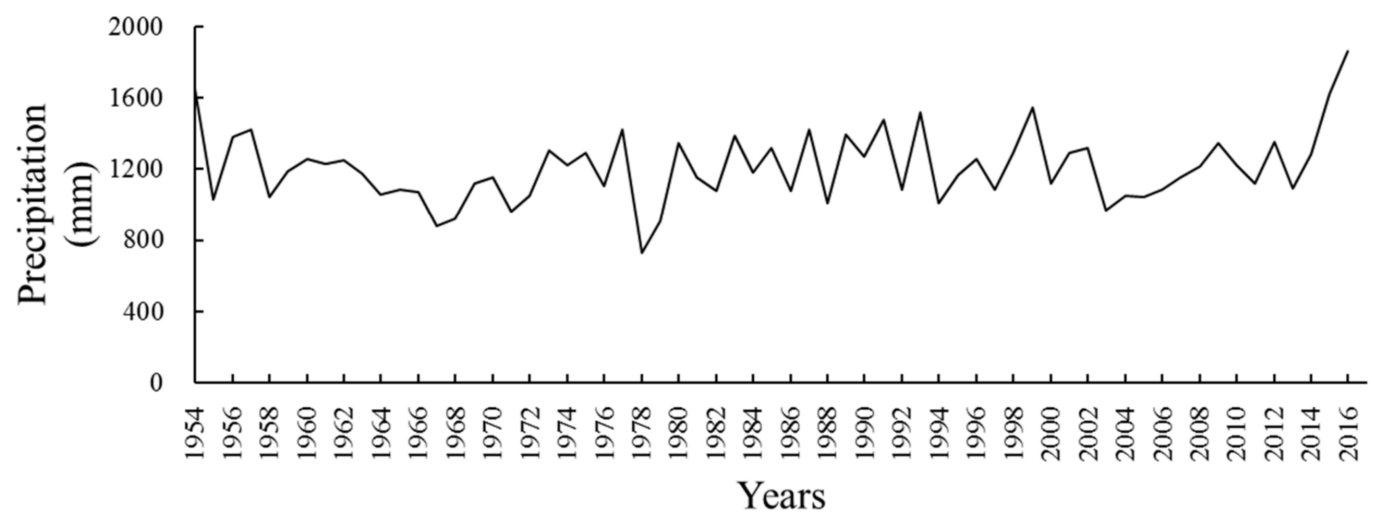

Figure 3. Precipitation in Taihu Lake Basin during 1954-2016.

According to Table 2, more than $70 \%$ of river water in Taihu Lake Basin is worse than Class-III water quality standards during 2003-2016, which cannot reach the national water quality standards for drinking water sources. There has a large gap between the amount of available drinking water and the drinking water demand. In addition, the percentage of water quality in the water function zone that meet the standard requirement is lower than $50 \%$, and the percentage that meet the standard for drinking water sources was only $50 \%$ in $2005,62.5 \%$ in 2006 , and $28.6 \%$ in 2007 . According to previous studies [45-50], the shortage of high-quality water, including drinking water, is an average of approximately 2.0-3.5 billion $\mathrm{m}^{3}$ for a normal year in Taihu Lake Basin. 
Table 2. Water resource and demand in Taihu Lake Basin.

\begin{tabular}{|c|c|c|c|c|}
\hline Year & $\begin{array}{c}\text { Total Water } \\
\text { Resource }\left(\mathbf{1 0}^{8} \mathrm{~m}^{3}\right)\end{array}$ & $\begin{array}{l}\text { Worse than Class-III } \\
\text { Standards River Water Rate * }\end{array}$ & $\begin{array}{l}\text { Drinking Water } \\
\text { Demand }\left(10^{8} \mathrm{~m}^{3}\right)\end{array}$ & $\begin{array}{c}\text { Quality Standard } \\
\text { Reaching Rate of Water } \\
\text { Function Zone }\end{array}$ \\
\hline 2003 & 110.6 & $90.60 \%$ & 22.5 & - \\
\hline 2004 & 125.9 & $93.50 \%$ & 23.5 & - \\
\hline 2005 & 133.7 & $89.70 \%$ & 24.4 & a $50.0 \%$ \\
\hline 2006 & 146.2 & $86.50 \%$ & 25.2 & a $62.5 \%$ \\
\hline 2007 & 172.7 & $85.70 \%$ & 26.6 & a $28.6 \%$ \\
\hline 2008 & 199.4 & $85.20 \%$ & 27.7 & - \\
\hline 2009 & 248.1 & $88.20 \%$ & 28.5 & - \\
\hline 2010 & 209.8 & $87.50 \%$ & 28.9 & b 5.1\% \\
\hline 2011 & 195.0 & $83.40 \%$ & 29.7 & b $14.2 \%$ \\
\hline 2012 & 233.3 & $81.30 \%$ & 30.4 & b 35.5\% \\
\hline 2013 & 160.5 & $80.10 \%$ & 31.7 & b 26.7\% \\
\hline 2014 & 228.9 & $75.70 \%$ & 30.9 & b $29.7 \%$ \\
\hline 2015 & 342.4 & $79.70 \%$ & 31.1 & b $27.9 \%$ \\
\hline 2016 & 439.2 & $71.80 \%$ & 32.0 & b $41.9 \%$ \\
\hline
\end{tabular}

* According to the Chinese national standard GB3838-2002 (environmental quality standard for surface water, 2002) [29]; a: Water function zoning for drinking water sources; b: All of the water function zones.

Meteorological droughts and water pollution both aggravate drinking water scarcity in Taihu Lake Basin. In Taihu Lake Basin, which has an abundance of water, a shortage of good quality drinking water is the reality at present. As one of the most populated, urbanized and industrialized regions in China, Taihu Lake Basin has experienced remarkable economic development with an annual gross domestic product growth rate of $15.7 \%$, an annual population growth rate of $3.0 \%$, and an annual urbanization growth rate of $9.2 \%$ over the past 30 years [51]. The rapid economic and social development in Taihu Lake Basin results in higher water resource requirements in regard to both quantity and quality. In the meantime, the industrial development, economic expansion and population growth could cause increasing amounts of organic substances, nutrients and heavy metals to be discharged into the water system and lead to more serious water pollution, resulting in an overall decline in the water quality of rivers and lakes in the basin.

\section{A Case Study in Yixing City, Taihu Lake Basin}

Yixing City is located west of Taihu Lake with a total area of $1996.6 \mathrm{~km}^{2}$, including $242.29 \mathrm{~km}^{2}$ from Taihu Lake, 215 rivers (total length of $1058 \mathrm{~km}$ and total area of $130 \mathrm{~km}^{2}$ ), more than 20 ponds (water area of $0.05 \mathrm{~km}^{2}$ ), and 20 reservoirs (total capacity of 126 million $\mathrm{m}^{3}$ ) as shown in Figure 4 . Although it appears that there is enough water, the amount of drinking water that meets the national quality standard is still insufficient and it is restricted to only a few reservoirs. In the past, the main drinking water source of Yixing City has been Xijiu Lake (Figure 5). However, due to a decline in water quality, water in Xijiu Lake cannot meet the national quality standard for drinking water sources. Since 2003 the main drinking water source of Yixing City was changed to the Hengshan Reservoir. Xijiu Lake is considered a backup water source, and is rarely used due to its poor water quality. 


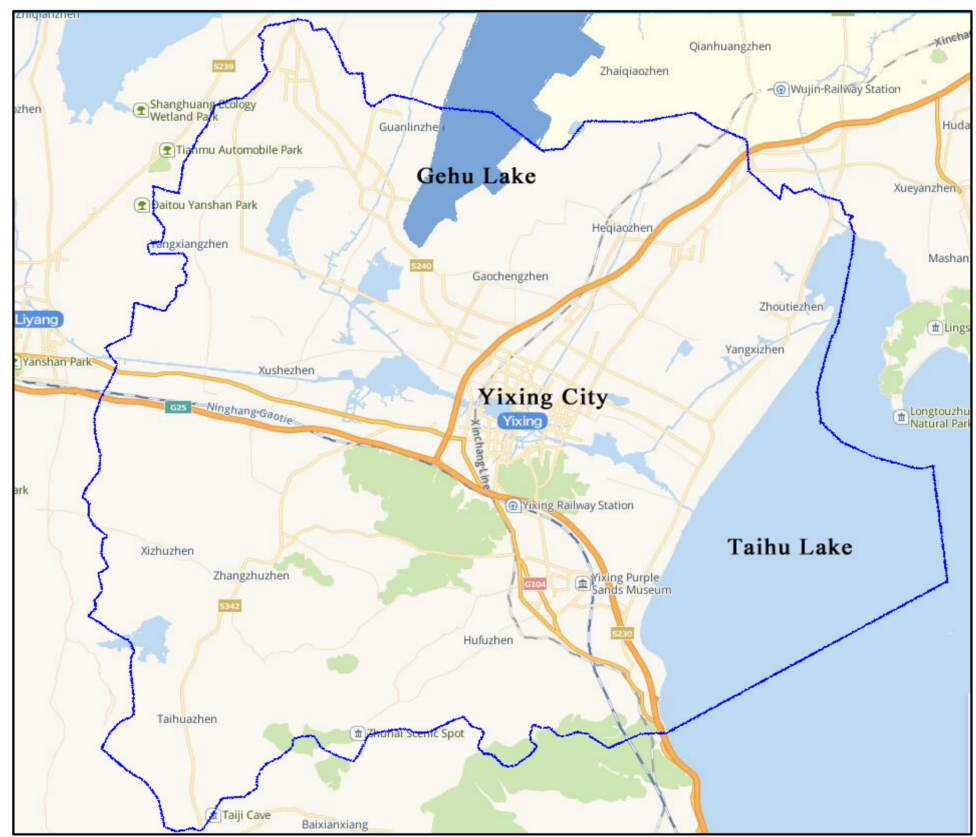

Figure 4. Location of Yixing City (the blue line represents the administrative region of Yixing City).

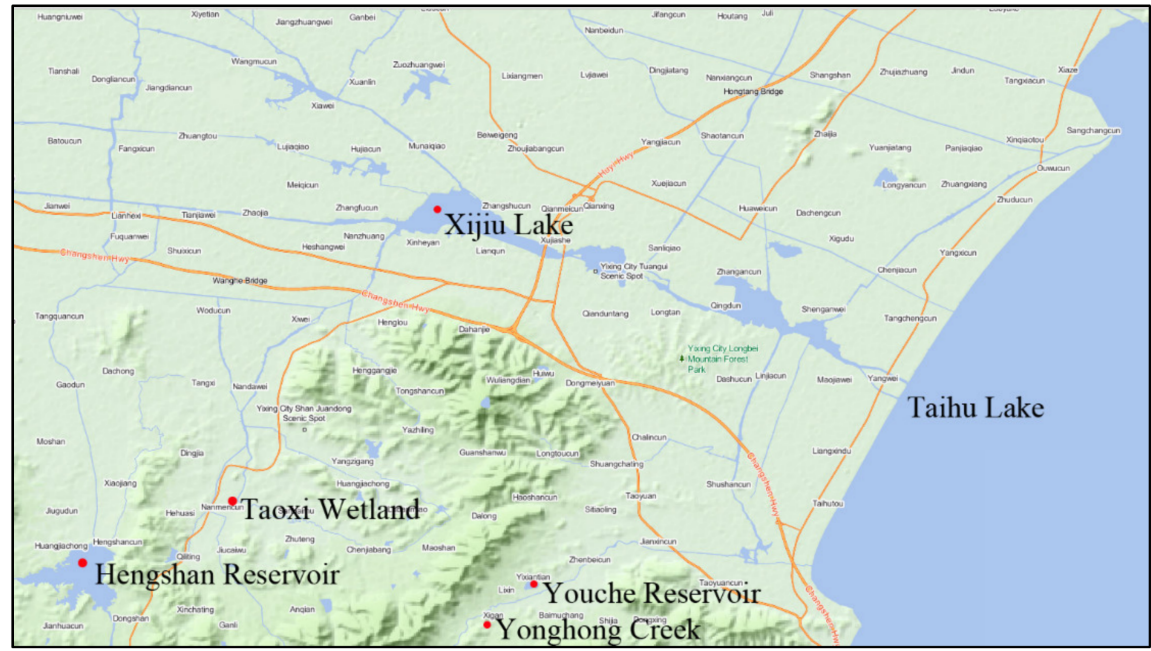

Figure 5. Current and future drinking water sources in reservoirs in Yixing City.

\subsection{Drought Event in 2011}

In 2011, precipitation in Taihu Lake Basin was notably less than in other years, approximately $60 \%$ less than the average value during the same period (Figure 3). From January to June, the severest drought in the past 60 years occurred in the whole basin [45]. The water level in Taihu Lake and the related river networks continually declined. The lowest water level in Taihu Lake was $2.74 \mathrm{~m}$ on 18 May, while the mean water level in Taihu Lake was $3.08 \mathrm{~m}$ during the same period. It indicated that there was 0.8 billion $\mathrm{m}^{3}$ less water in the lake in 2011. The government has prescribed that the lowest allowed water level in the Taihu Lake is $2.8 \mathrm{~m}$. However, during 16 April-5 June, water levels in Taihu Lake only met the standard for 5 days. In 2011, not only was the amount of water reduced due to the meteorological drought, but the water quality also deteriorated in the lake. According to the Taihu Lake Basin Water Resources Protection Bureau [36], water quality in Taihu Lake was worse than Class-III standards for all of 2011. During April-July, the quality of most water in Taihu Lake was worse than Class-V standards due to eutrophication and blue algal blooms. These waters with poor quality cannot be used as a drinking water source. 
Figure 6 shows the annual precipitation in Yixing City from 1980 to 2014. The average annual precipitation in Yixing City is $1306 \mathrm{~mm}$. In recent years, the annual precipitation has been relatively low, such as in 1997, 2004, 2007, and 2013. The annual precipitation in 2011 was approximately $1499.6 \mathrm{~mm}$, which is higher than in 2010 and 2012. However, the amount of precipitation in Yixing City is uneven throughout the year.

The SPI index is calculated using monthly precipitation data in Yixing City from 1980 to 2014. Figure 7a,b shows the SPI values of Yixing City with time scales of three and six months from 1980 to 2014. Dry periods occur 13-15\% of the time according to historical data from Yixing City (Table 3). A severe drought event occurred from February to July 2011 according to the SPI index.

In 2011, the water level in Hengshan Reservoir, the main drinking water source of Yixing City, was much lower due to less precipitation and less inflow runoff [52]. The lowest annual water level in Hengshan Reservoir from 2004 to 2011 is shown in Figure 8. The lowest annual water level usually occurs in winter (November, December, and January), but it unusually occurred in June 2011. The lowest annual water level was $24.33 \mathrm{~m}$ in 2011 , which almost reached the dead water level $(24.0 \mathrm{~m})$.

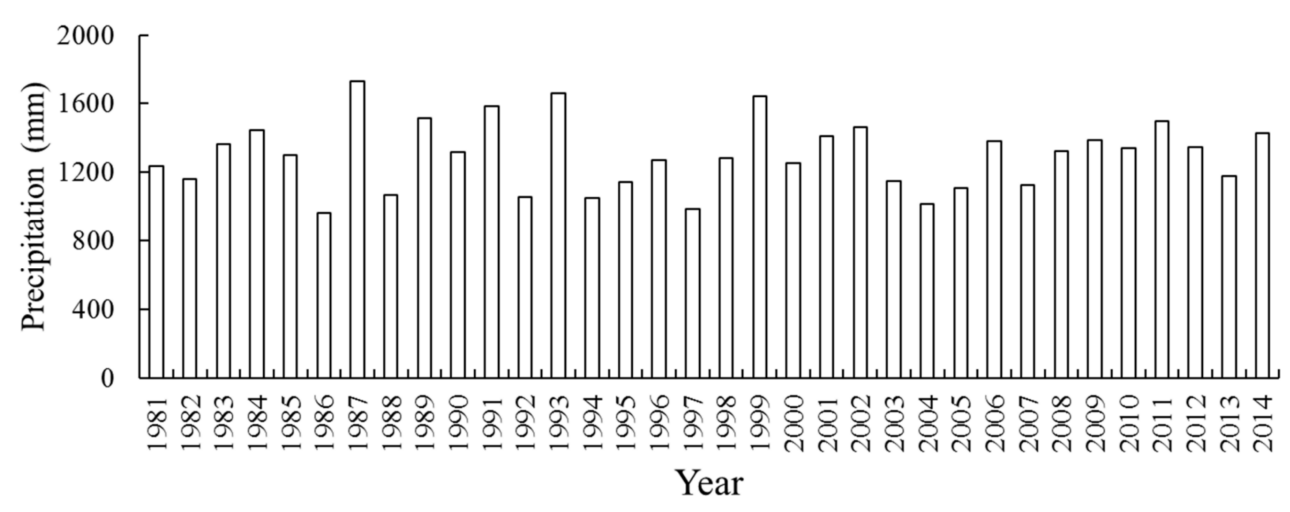

Figure 6. Annual precipitation in Yixing City from 1980 to 2014.

(a) Standardized Precipitation Index (SPI)-3 Months

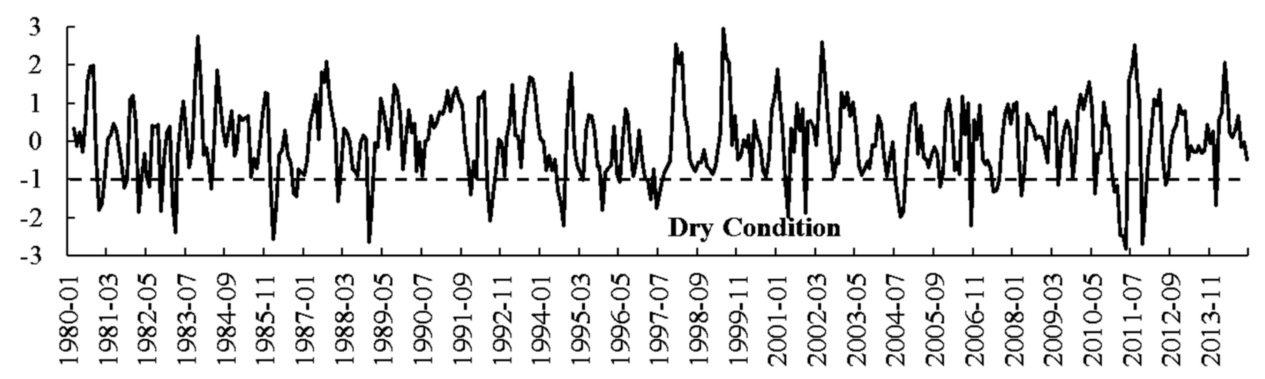

(b) Standardized Precipitation Index (SPI)-6 Months

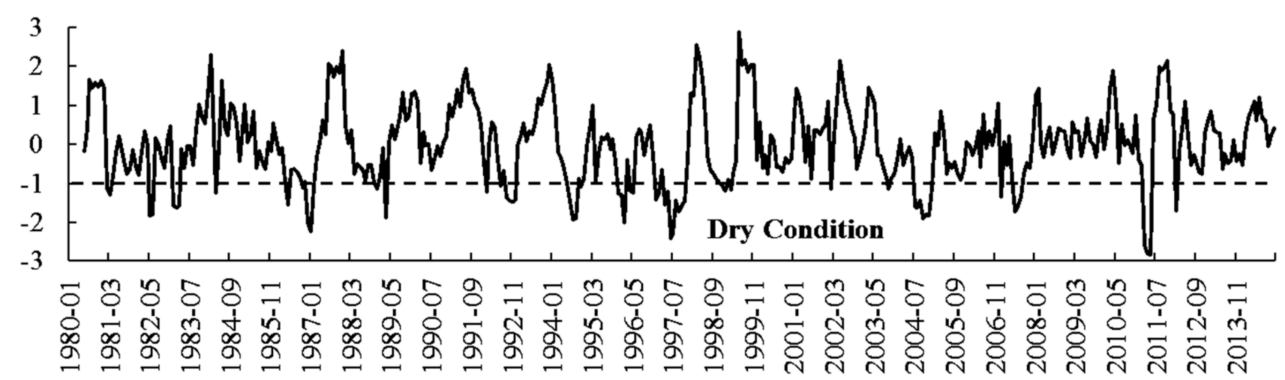

Figure 7. Standardized Precipitation Index of Yixing City for three and six month timescales from 1980 to 2014. (a) Standardized Precipitation Index (SPI)-3 Months; (b) Standardized Precipitation Index (SPI)-6 Months. 


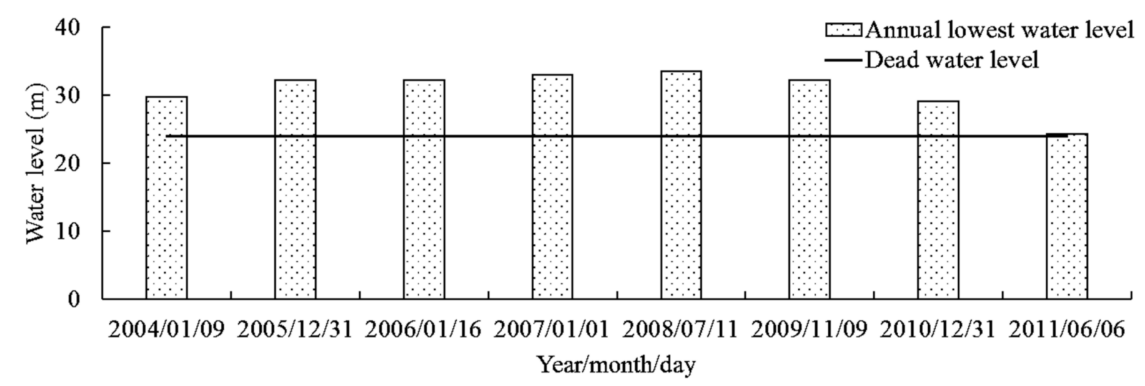

Figure 8. Lowest water levels in Hengshan Reservoir from 2004 to 2011.

Table 3. Three- and six-month SPI values for Yixing City from 1980 to 2014.

\begin{tabular}{cccc}
\hline SPI Class & $\begin{array}{c}\text { Three Month SPI } \\
\text { Values in Yixing City }\end{array}$ & $\begin{array}{c}\text { Six Month SPI Values } \\
\text { in Yixing City }\end{array}$ & Interpretation \\
\hline 2.0 & $2.63 \%$ & $3.13 \%$ & Extremely wet \\
1.5 to 1.99 & $3.59 \%$ & $4.58 \%$ & Severely wet \\
1.0 to 1.49 & $10.05 \%$ & $9.88 \%$ & Moderately wet \\
0.99 to -0.99 & $70.33 \%$ & $67.71 \%$ & Near normal \\
-1.0 to -1.49 & $6.46 \%$ & $7.95 \%$ & Moderately dry \\
-1.5 to -1.99 & $4.55 \%$ & $4.82 \%$ & Severely dry \\
$\leq-2.0$ & $2.39 \%$ & $1.93 \%$ & Extremely dry \\
\hline
\end{tabular}

\subsection{Coping Measures}

As the main drinking water source of Yixing City, the original planned water supply of Hengshan Reservoir was $5.7 \times 10^{7} \mathrm{~m}^{3} /$ year. With development of the economy and the rise in population, the water demand in Yixing City is continually increasing. In 2011, the real water supply from Hengshang Reservoir was $8.15 \times 10^{7} \mathrm{~m}^{3}, 43 \%$ higher than the planned water supply amount. However, it still cannot meet the increasing water demand, especially in drought years such as 2011. From Figure 9, it can be seen that the total water demand of Yixing City is much higher than the water taken from Hengshan Reservoir from 15 February to 11 June 2011. To fix the huge water demand gap, water from Xijiu Lake was used as a backup drinking water source during the drought event in 2011, although the water quality in Xijiu Lake does not reach the national standard for drinking water sources in China. Water taken from Xijiu Lake was approximately $4.6 \times 10^{4} \mathrm{~m}^{3}$ on 15 February and increased to approximately $1.7 \times 10^{5} \mathrm{~m}^{3}$ on 11 June. During these 117 days, the total amount of water taken from Xijiu Lake was approximately $1.4 \times 10^{7} \mathrm{~m}^{3}$, providing $37.13 \%$ of the city's water supply. Table 4 shows the daily maximum,-minimum, -average and the total amount of water from Xijiu Lake with poor quality and water from Hengshan Reservoir with high quality during the drought period. The highest ratio of poor quality water to high quality water was 0.90:1.

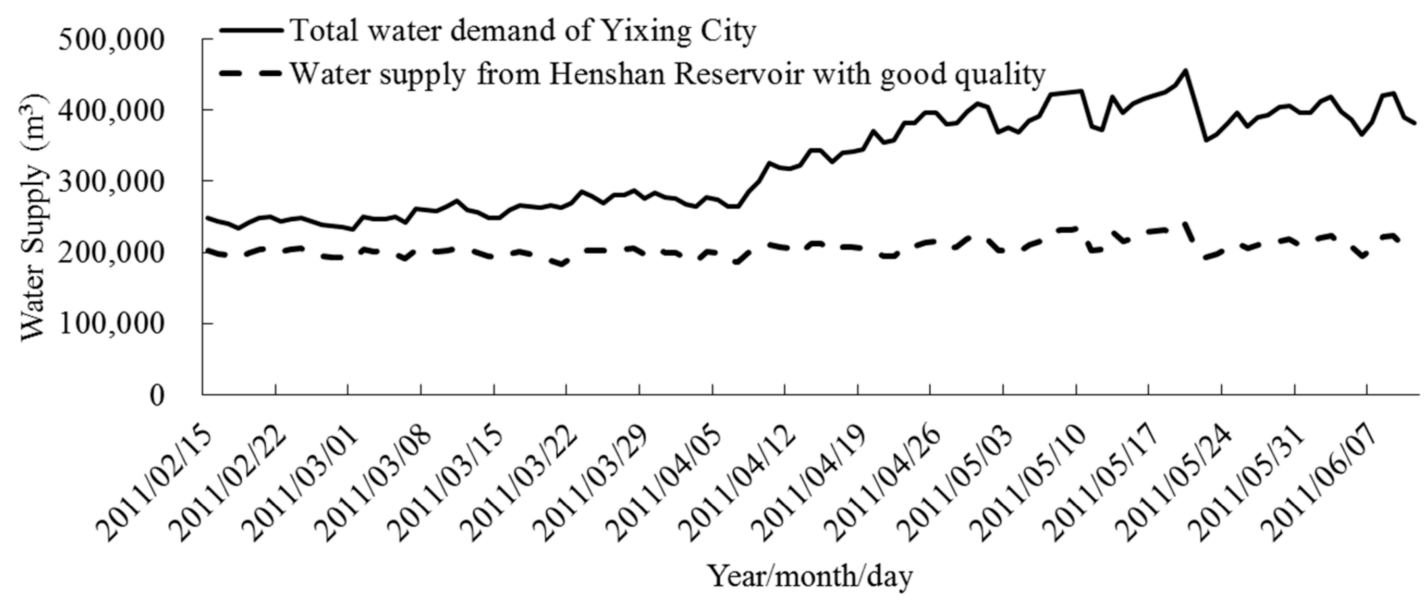

Figure 9. Water demand in Yixing City in 2011. 
Table 4. Amounts of poor- and high-quality water during a drought event in 2011.

\begin{tabular}{ccccc}
\hline Water Amount $\left.\mathbf{( m}^{\mathbf{3}}\right)$ & Daily Maximum & Daily Minimum & Daily Average & Total Amount \\
\hline Poor quality water & 216,321 & 40,898 & 121,666 & $14,234,906$ \\
High quality water & 240,229 & 192,029 & 206,035 & $24,106,113$ \\
Ratio & $0.90: 1$ & $0.21: 1$ & $0.59: 1$ & $0.59: 1$ \\
\hline
\end{tabular}

It is concerning that water from Xijiu Lakeis too poor to be used as a drinking water source. Water quality indices including chemical oxygen demand (COD), biochemical oxygen demand (BOD), ammonia nitrogen $\left(\mathrm{NH}_{3}-\mathrm{N}\right)$, total nitrogen $(\mathrm{TN})$, total phosphorus $(\mathrm{TP})$, iron $(\mathrm{Fe})$, manganese $(\mathrm{Mn})$, and petroleum were measured once a month when water was being pumped from Xijiu Lake in 2011. As shown in Figure 10, measured concentrations of the eight indices in Xijiu Lake were higher than the critical values most of the time during the water pumping period. The maximum concentrations of COD and Fe were more than twice the critical value (Table 5). The maximum concentration of $\mathrm{TP}$ was more than four times the critical value, $\mathrm{NH}_{3}-\mathrm{N}$ was eight times higher, and both $\mathrm{TN}$ and petroleum were almost 20 times higher their critical values. Even so, this poor quality water was still used as a drinking water source during the drought event in 2011. The water treatment processes were extremely expensive.

Table 5. Measured maximums during the 2011 water pumping period and the critical values of Class-II water in the Chinese Environmental Quality Standards for Surface Water (mg/L).

\begin{tabular}{ccccccccc}
\hline Index & COD & BOD & NH3-N & TN & TP & Fe & Mn & Petroleum \\
\hline Measured Maximums & 40.4 & 5.3 & 4.51 & 9.51 & 0.4 & 0.72 & 0.17 & 1.30 \\
Critical Values & 15 & 3 & 0.5 & 0.5 & 0.1 & 0.3 & 0.1 & 0.05 \\
\hline
\end{tabular}

Drinking water scarcity has become a serious threat in Yixing City. To relieve the stress of increasing demands of good quality water, Youche Reservoir was constructed and used as a new source of drinking water for Yixing City since July 2013. Taoxi Wetland and Yonghong Creek are planned to be built as future drinking water sources (Figure 5). Many scholars put great effort into predicting the variation in future drinking water sources and exploring the influence of global climate change and human activities. In addition, the Chinese government has spent billions on researching drinking water problems in key river basin and lakes, including Taihu Lake Basin, since 2012. One of the major projects called "Major Science and Technology Program for Water Pollution Control and Treatment" has been implemented in Yixing City. It cost 0.18 billion Yuan and aims to relieve the drinking water shortage.

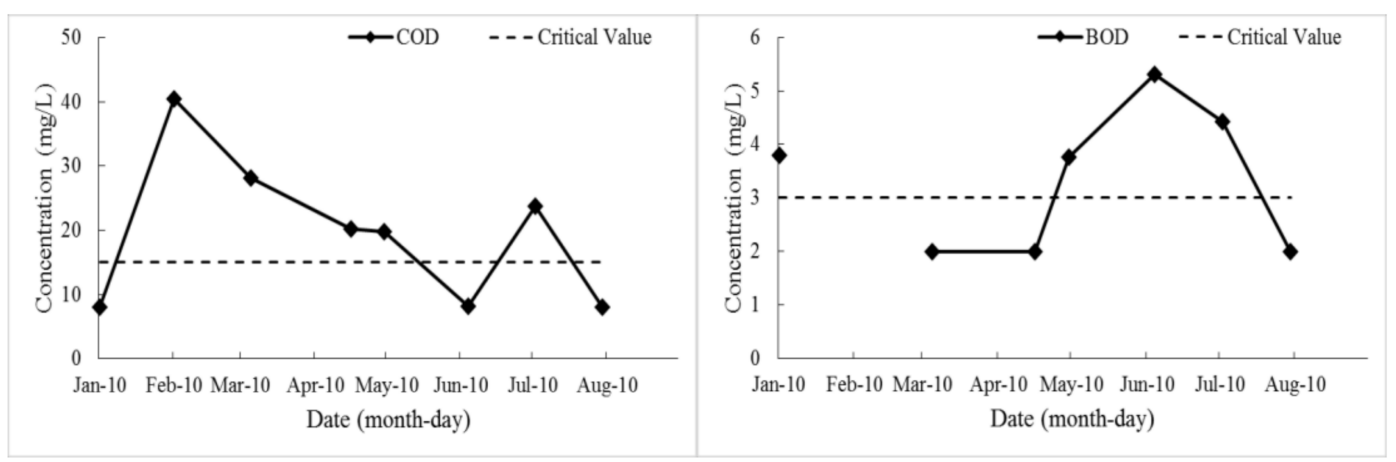

Figure 10. Cont. 

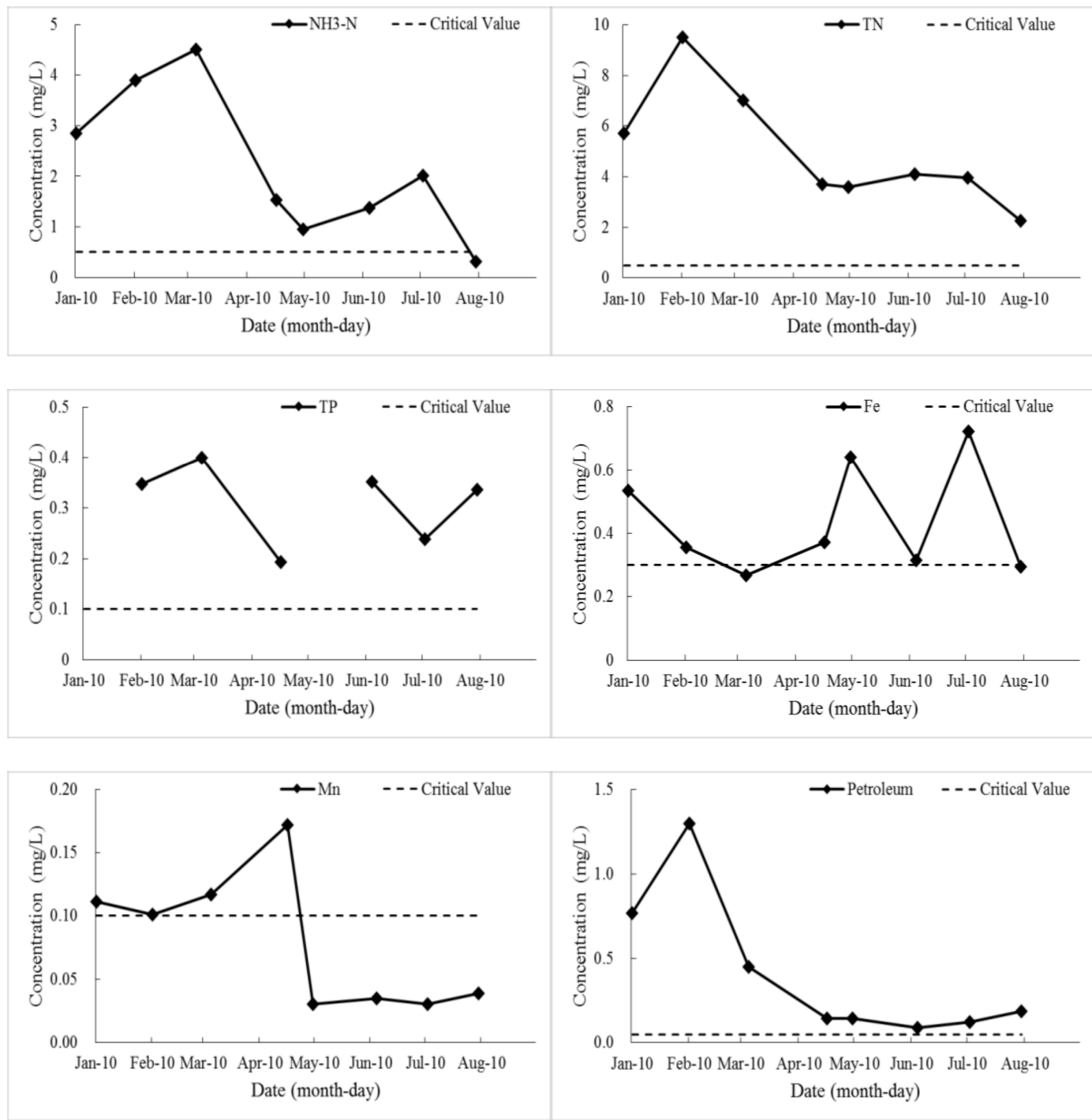

Figure 10. Water quality indices (COD, BOD, NH3-NTN, TP, Fe, Mn, and Petroleum) in Xijiu Lake during 2011, showing poor water quality that does not meet the standards for drinking water sources.

\section{Conclusions}

Drinking water scarcity has become a serious issue in the whole world. It occurs not only in arid and semiarid regions but also in water-rich regions such as those in Taihu Lake Basin. It is both a natural and human-made phenomenon. Both meteorological droughts and declines in water quality could result in drinking water shortages, which requires the attention of the entire society. In some areas, there is enough water, but most of it is wasted, polluted or unsustainably managed. Taking Yixing City in Taihu Lake Basin as an example, poor-quality water from Xijiu Lake was used as a drinking water source during the drought event in 2011. Many people were affected in this drinking water crisis and it cost a lot in the water treatment processes. Many measures should be taken to alleviate drinking water scarcity in water-rich regions such as Tiahu Lake Basin.

1. Optimal regulation on water resource under the joint operation of both water quantity and quality. In water-rich regions where have plenty water, the optimal regulation on water resource should be based on the water quantity for reasonable demand of the local water users and the water quality to ensure the water supply security. It is an economic and efficient method to alleviate the shortage of drinking water and protect the water environment. 
2. Strict protection on the current water source area, such as controlling pollution emitted into water considering water environmental capacity and the quality standard of water function zone, use of the remote monitor and control system in water resources management, enforcing laws and regulations for water protection.

3. Promoting water purification technology and advocating water recycling.

4. Seeking new drinking water sources with good quality water.

Author Contributions: Conceptualization and methodology, S.L. (Sha Lou) and W.H.; investigation, G.Z.; data curation, S.L. (Sha Lou) and S.L. (Shuguang Liu); writing-original draft preparation, S.L. (Sha Lou); writing-review and editing, S.L. (Sha Lou), W.H., S.L. (Shuguang Liu) and G.Z.; funding acquisition, S.L. (Sha Lou) and S.L. (Shuguang Liu).

Funding: This work was sponsored by the Fundamental Research Funds for the Central Universities of China (22120180095), the Natural Science Foundation of China (41602244) and the National Key Research and Development Program of China (2018YFD1100401).

Acknowledgments: The authors thank the anonymous reviewers, Associate Editor and Editor for their constructive comments.

Conflicts of Interest: The authors declare no conflict of interest.

\section{References}

1. Tao, T.; Xin, K. Public health: A sustainable plan for China's drinking water. Nat. Comment 2014, 511, 527-528. [CrossRef] [PubMed]

2. WWAP (United Nations World Water Assessment Programme. The United Nations World Water Development Report 2017: Wastewater, The Untapped Resource; United Nations Educational, Scientific and Cultural Organization (UNESCO): Paris, France, 2017.

3. Vorosmarty, C.J.; McIntyre, P.B.; Gessner, M.O.; Dudgeon, D.; Prusevich, A.; Green, P.; Glidden, S.; Bunn, S.E.; Sullivan, C.A.; Liermann, C.R.; et al. Global threats to human water security and river biodiversity. Nature 2010, 467, 555-561. [CrossRef] [PubMed]

4. Water Resource Institute. 2016. Available online: https://www.wri.org/our-work/topics/water (accessed on 8 November 2017).

5. Organisation for Economic Cooperation and Development (OECD). OECD Environmental Outlook to 2050-The Consequences of Inaction; OECD Publishing: Paris, France, 2012. [CrossRef]

6. Rijsberman, F.R. Water scarcity: Fact or fiction? Agric. Water Manag. 2006, 80, 5-22. [CrossRef]

7. Safriel, U.; Adeel, Z.; Niemeijer, D.; Puigdefabregas, J.; White, R.; Lal, R.; Winslow, M.; Ziedler, J.; Prince, S.; Archer, E.; et al. Dryland Systems. Millennium Ecosystem Assessment: Ecosystems and Human Well-Being: Current State and Trends; Hassan, R.M., Scholes, R., Ash, N., Eds.; Island Press: Washington, DC, USA, 2005; Volume 1, pp. 623-662.

8. WWDR3. Water in a Changing World. World Water Development Report. 2009. Available online: http:// www.unesco.org/new/en/natural-sciences/environment/water/wwap/wwdr/wwdr3-2009/ (accessed on 8 November 2017).

9. Wallace, J.S. Increasing agricultural water efficiency to meet future food production. Agric. Ecosyst. Environ. 2000, 82, 105-119. [CrossRef]

10. Arenas-Sanchez, A.; Rico, A.; Vighi, M. Effects of water scarcity and chemical pollution in aquatic ecosystems: State of the art. Sci. Total Environ. 2016, 572, 390-403. [CrossRef] [PubMed]

11. Molinos-Senante, M.; Donoso, G. Water scarcity and affordability in urbanwater pricing: A case study of Chile. Util. Policy 2016, 43, 107-116. [CrossRef]

12. European Union. Water Scarcity and Drought in the European Union. 2010. Available online: http://ec. europa.eu/environment/water/quantity/pdf/brochure.pdf (accessed on 8 November 2017).

13. MMA (Ministerio de Medio Ambiente. Informe Evaluación Preliminar General de los Impactos en España por Efectos del Cambio Climático; Ministerio de Medio Ambiente: Madrid, Spain, 2005.

14. Kahil, M.T.; Dinar, A.; Albiac, J. Cooperative water management and ecosystem protection under scarcity and drought in arid and semiarid regions. Water Resour. Econ. 2016, 13, 60-74. [CrossRef] 
15. DeNicola, E.; Aburizaiza, O.S.; Siddique, A.; Khwaja, H.; Carpenter, D.O. Climate Change and Water Scarcity: The Case of Saudi Arabia. Ann. Glob. Health 2015, 81, 342-353. [CrossRef] [PubMed]

16. Hadadin, N.; Qaqish, M.; Akawwi, E.; Bdour, A. Water shortage in Jordan-Sustainable solutions. Desalination 2010, 250, 197-202. [CrossRef]

17. Li, S.T. Urban Water Pollution Issues. China Youth. 2006. Available online: http://news.xinhuanet.com/ environment/2006-09/13/content_5084123.htm (accessed on 8 November 2017).

18. MWR (Ministry of Water Resources, P.R. China). The 11th Five-Year Plan of National Water Resources Development; Gazette of the Ministry of Water Resources of the P.R. China: Beijing, China, 2007; pp. $34-48$.

19. Jiang, Y. China's water security: Current status, emerging challenges and future prospects. Environ. Sci. Policy 2015, 54, 106-125. [CrossRef]

20. Pradhan, N.S.; Su, Y.; Fu, Y.; Zhang, L.; Yang, Y. Analyzing the Effectiveness of Policy Implementation at the Local Level: A Case Study of Management of the 2009-2010 Drought in Yunnan Province. China. Int. J. Disaster Risk Sci. 2017, 8, 64-77. [CrossRef]

21. Ludwig, R.; Roson, R.; Zografos, C.; Kallis, G. Towards an inter-disciplinary research agenda on climate change, water and security in Southern Europe and neighboring countries. Environ. Sci. Policy 2011, 14, 794-803. [CrossRef]

22. Sjerps, R.M.A.; Laak, T.L.; Zwolsman, G.J.J.G. Projected impact of climate change and chemical emissions on the water quality of the European rivers Rhine and Meuse: A drinking water perspective. Sci. Total Environ. 2017, 601-602, 1682-1694. [CrossRef] [PubMed]

23. RIWA-Meuse. The Quality of Meuse Water in 2015; Association of River Water Companies: Rotterdam, Netherlands, 2016.

24. European Environment Agency (EEA). Chemical Status of Rivers and Lakes; EEA: Copenhagen, Denmark, 2012.

25. Internationale Arbeitsgemeinschaft der Wasserwerke im Rheineinzugsgebiet (IAWR). Memorandum Regarding the Protection of European Rivers and Watercourses in Order to Protect the Provision of Drinking Water; IAWR: Karlsruhe, Germany, 2013; p. 28.

26. Rahman, M.T.U.; Rasheduzzaman, M.; Habib, M.A.; Ahmed, A.; Tareq, S.M.; Muniruzzaman, S.M. Assessment of fresh water security in coastal Bangladesh: An insight from salinity, community perception and adaptation. Ocean Coast. Manag. 2016, 137, 68-81. [CrossRef]

27. Abedin, M.A.; Shaw, R. Constraints and coping measures of coastal community toward safe drinking water scarcity in Southwestern Bangladesh. In Science and Technology in Disaster Risk Reduction in Asia, Potentials and Challenges; Elsevier: Amsterdam, The Netherlands, 2018; pp. 431-452.

28. Hoque, R.M. Access to Safe Drinking Water in Rural Bangladesh: Water Governance by DPHE; Institute of Governance Studies, BRAC University: Dhaka, Bangladesh, 2009.

29. Environmental Quality Standard for Surface Water, GB3838-2002; Ministry of Environmental Protection of the People's Republic of China: Beijing, China, 2002. (In Chinese)

30. MWR (Ministry of Water Resources, P.R. China). Bulletin of Water Resource in China 2015; Ministry of Water Resources: Beijing, China, 2015.

31. Gao, J.; Christensen, P.; Li, W. Application of the WEAP model in strategic environmental assessment: Experiences from a case study in an arid/semi-arid area in China. J. Environ. Manag. 2017, 198, 363-371. [CrossRef] [PubMed]

32. Yue, W.; Liu, X.; Wang, T.; Chen, X. Impacts of water saving on groundwater balance in a large-scale arid irrigation district, Northwest China. Irrig. Sci. 2016, 34, 297-312. [CrossRef]

33. Zhang, J.; Ding, Z.; Luo, M. Risk analysis of water scarcity in artificial woodlands of semi-arid andarid China. Land Use Policy 2017, 63, 324-330. [CrossRef]

34. Zhang, J.; Yang, J.; An, P.; Ren, W.; Pan, Z.; Dong, Z.; Han, G.; Pan, Y.; Pan, S.; Tian, H. Enhancing soil drought induced by climate change and agricultural practices: Observational and experimental evidence from the semiarid area of northern China. Agric. For. Meteorol. 2017, 243, 74-83. [CrossRef]

35. Qin, B.; Zhu, G.; Gao, G.; Zhang, Y.; Li, W.; Paerl, H.W.; Carmichael, W.W. A Drinking Water Crisis in Lake Taihu, China: Linkage to Climatic Variability and Lake Management. Environ. Manag. 2010, 45, 105-112. [CrossRef] [PubMed]

36. Taihu Lake Basin WATER Resources Protection Bureau. Taihu Lake Basin and Southeast Rivers Water Quality Bulletin; Taihu Lake Basin WATER Resources Protection Bureau: Shanghai, China, 2007; pp. 2011-2015. 
37. Oki, T.; Kanae, S. Global hydrological cycles and world water resources. Science 2006, 313, $1068-1072$. [CrossRef] [PubMed]

38. McKee, T.B.; Doesken, N.J.; Kliest, J. The relationship of drought frequency and duration to time scales. In Proceedings of the 8th Conference of Applied Climatology, Anaheim, CA, USA, 17-22 January 1993; American Meteorological Society: Boston, MA, USA, 1993; pp. 179-184.

39. He, J.; Yang, X.; Li, Z.; Zhang, X.; Tang, Q. Spatiotemporal Variations of Meteorological Droughts in China During 1961-2014: An Investigation Based on Multi-Threshold Identification. Int. J. Disaster Risk Sci. 2016, 7, 63-76. [CrossRef]

40. Kharraz, J.E.; El-Sadek, A.; Ghaffour, N.; Mino, E. Water scarcity and drought in WANA countries. Procedia Eng. 2012, 33, 14-29. [CrossRef]

41. Koudahe, K.; Kayode, A.J.; Samson, A.O.; Adebola, A.A.; Djaman, K. Trend Analysis in Standardized Precipitation Index and Standardized Anomaly Index in the Context of Climate Change in Southern Togo. Atmos. Clim. Sci. 2017, 7, 401-423. [CrossRef]

42. Opiyo, F.; Wasonga, O.; Nyangito, M.; Schilling, J.; Munang, R. Drought Adaptation and Coping Strategies Among the Turkana Pastoralists of Northern Kenya. Int. J. Disaster Risk Sci. 2015, 6, 295-309. [CrossRef]

43. Deng, X.; Xu, Y.; Han, L.; Yang, M.; Yang, L.; Song, S.; Li, G.; Wang, Y. Spatial-temporal evolution of the distribution pattern of river systems in the plain river network region of the Taihu Basin, China. Q. Int. 2016, 392, 178-186. [CrossRef]

44. Bureau of Taihu Lake Basin. Taihu Lake Basin and Southeast Rivers Water Resource Bulletin; Bureau of Taihu Lake Basin: Shanghai, China, 2003-2016.

45. Jin, K.; Zhang, X.; Liang, Z.; You, Z. Influence of water division from the Yangtze River on the relief of drought event in Taihu Lake Basin. China Flood Drought Manag. 2014, 24, 20-23. (In Chinese)

46. Geng, Y.; Zhu, W.; Wang, T. Water Quality Assessment and Shortage Analysis Caused by Pollution in the Taihu Basin. J. Lake Sci. 2003, 15, 255-260. (In Chinese)

47. Wang, C. Shortage of Clean Water in Shanghai and the Main Cause. Special Topic Report. 2012. Available online: http:/ / www.doc88.com/p-9052357077446.html (accessed on 4 December 2017). (In Chinese)

48. Zhu, W. Water Scarcity Caused by Pollution in the Taihu Basin. J. Lake Sci. 2003, 5, 133-138. (In Chinese)

49. Zhu, W.; Geng, Y. Problems, configuration, and protection countermeasures in the development and use of water resource in the Taihu Basin. In Proceedings of the Advanced Forum about the Taihu Basin, Shanghai, China, December 2004; pp. 151-155. (In Chinese)

50. Ye, S. Current status of water resource in the Taihu Basin. In Proceedings of the advanced forum about the Taihu Basin, Shanghai, China, December 2004; pp. 119-124. (In Chinese)

51. Xu, X.; Yang, G.; Tan, Y.; Zhuang, Q.; Li, H.; Wan, R.; Su, W.; Zhang, J. Ecological risk assessment of ecosystem services in Taihu Lake Basin of China from 1985 to 2020. Sci. Total Environ. 2016, 554-555, 7-16. [CrossRef] [PubMed]

52. Zhu, L.; Jia, X.; Xu, X.; Qin, J. Analysis of dead water level in Henshang Reservoir. Water Conserv. Sci. Technol. Econ 2015, 21, 26-27. (In Chinese)

(C) 2019 by the authors. Licensee MDPI, Basel, Switzerland. This article is an open access article distributed under the terms and conditions of the Creative Commons Attribution (CC BY) license (http:/ / creativecommons.org/licenses/by/4.0/). 